\section{GRASSHOPPER EGGS LAID IN SWEET CLOVER STEMS}

\author{
by Cliff Matthews, Saskatoon
}

In 1961 we received some sweet clover stems with eggs of some insect laid right in the stem. That winter we incubated these eggs; only one hatched and the hatchling lived only four days. However, we were able to identify it as the nymph of the grasshopper Pseudopomola brachyptera.

We were astonished that this insect should turn out to be a grasshopper as this is (so far as we know) the first known instance of a grasshopper with this habit. The ovipositor of a grasshopper is not adapted to boring into woody stems and if the eggs were laid in the broken or cut end of the stem what kind of acrobatics the grasshopper must have had to go through!

These eggs were found by $\mathrm{Mr}$. Alex Vadelboncoeur at Val Marie, Saskatchewan, along the railroad right of way. The sweet clover had been cut, but we don't know if the eggs were laid in the cut part of the stem or that left standing. The only other Canadian record of Pseudopomala brachyptera is from Onefour, Alberta-we have four in the station collection from this location.

If any Blue Jay readers notice what might be grasshopper eggs laid in sweet clover or other woody stems, it would be appreciated if these eggs were sent to us so that we could again attempt to hatch them. 9. Please send to me or

Roy Pickford,

Canada Dept. of Agriculture,

Research Station, University Sub P.O. Saskatoon, Sask.

\section{"VELVET ANTS"}

by John V. Hodges, Regina

Ants have become familiar companions for those of us who have been conducting archaeological investigations during the last nine years at the site we refer to as EdNh-1. Imagine our surprise, then, when what appeared to be a new species of ant walked across the area being trowelled one day last summer. This insect, which none of us had seen be- fore, was identified as a "velvet ant", which is not an ant at all, but a wasp. This specimen was collected and brought to our home for further observation, then sent to the Research Branch of the Central Experimental Farm, Ottawa, for positive identification. Dr. W. R. M. Mason identified it as Dasymutilla bioculata (Cress.), a northern species of wasp.

These wasps are called velvet ants because the female is wingless and ant-like in appearance. The body is covered with fine, colorful, glossy hair. The writer allowed the insect to crawl around on his hands but this is not recommended. The insect is a true wasp, equipped to sting, and its sting is very painful. This applies only to the female, for the much smaller, winged male does not bite.

In order to photograph the wasp it was refrigerated to slow down its movements. It rcovered quickly, but when it was restrained a squeaking sound was heard to come from its abdomen. The sound seemed to result from the insect moving its abdomen in a vertical plane causing the second last segment to be rubbed over the last segment. The piping sound was clearly audible and was successfully recorded on tape by Bernard Haysom. It was only heard if the insect was irritated and seemed related to its preparation to sting.

The stinger which protrudes from the rear upon attack is a very long needle-like device almost as long as the abdomen itself. It strikes very fast, so we were fortunate to get a colour photograph showing this rapier-like stinger fully extended.

The wasp had a bright red head, thorax and front abdomen. The rear half of the abdomen was black but a fine white line showed the location of the rear edge of the last two segments. It measured half an inch in length.

The female wasp must have been engaged in egg laying when one of our trowels uncovered her. She does this by following the burrow of some larval insect and then stinging it. She then lays an egg in the paralysed insect's body which will provide food for the developing young wasp. It was interesting to learn about this insect and its habits in the middle of our archaeological investigations. 